\title{
Research on Innovation Path of Educational Management Mode in Colleges and Universities from the Perspective of Intelligent Education
}

\author{
Chen min
}

Zhejiang Financial College, Zhejiang HangZhou, 310018, China

\begin{abstract}
Under the background of the development of the times and the continuous innovation of science and technology, the rapid development of network information technology, intelligent education relying on the strong network information technology into the education management industry, for the education industry to bring development opportunities and challenges. At present, most colleges and universities in our country have the conditions to carry out intelligent education. The use of intelligent education in the teaching management of colleges and universities promotes the upgrading of the management mode of colleges and universities, and improves the ability and efficiency of the management of colleges and universities. The ultimate goal of wisdom education is to improve students' thinking ability, labor ability and problem-solving ability through the change of students' management mode, and to cultivate talents with all-round development for the future society.
\end{abstract}

Keywords:wisdom education; university education management mode; innovation path

With the development of science and technology, the Internet and big data as the background of the new era, network information technology in people's lives occupy more and more fields, digital products have become an indispensable and indispensable thing in people's lives. With the support of

https://doi.org/10.47852/bonviewCETR2020010225

This is an open access article published by the BON VIEW PUBLISHING PTE. under the Creative Commons Attributions License. 
information technology, intelligent education has led the new trend of the development of education industry. The application of wisdom education in the management of colleges and universities, on the one hand, promotes the integration and sharing of high-quality educational resources in colleges and universities, and breaks the shackles of the traditional teaching mode for the cultivation of compound talents. Let students choose the appropriate educational resources through the wisdom education learning platform. On the other hand, wisdom education promotes students"” autonomous "learning. Students can use various digital terminals to obtain the required learning materials on the learning platform of wisdom education. College education and university management have the characteristics of autonomy at the same time. Finally, the wisdom education also realizes the export of new research results through the deep integration and development of production, learning and research. From the perspective of intelligent education, the management and education mode of colleges and universities have been revolutionary and updated on the basis of the integration of big data and network information technology.

\section{The integration of production, study and research in colleges and universities needs the support of wisdom education}

Education management has become the task of the whole society, no longer just the task of school administrators and education authorities. At present, the management mode of colleges and universities is constantly changing under the background of the rapid development of information technology. Intelligent education is a new educational idea based on the big data era and the inevitable result of the development of educational informatization. Education managers should conform to the development of the information digital age and improve their management level on the basis of the new information technology, so as to play a positive role as the promoter of educational development. From the technical point of view, wisdom education links the information of all departments of the school, and provides all kinds of resources needed for learning for all teachers and students to share, so as to promote the deep integration of colleges and universities "production, learning, research ".Through the wisdom education platform, educators can strengthen the communication with students and organize students to discuss favorite topics, so as to promote the deep integration of students' learning aspects of "production, learning, research",[1].

\section{Building the Intelligent Education Platform in Colleges and Universities}

Resources, learners, learning activities, equipment, promoting scholars are all the contents of 
wisdom education. Learners' learning is based on educational resources and learning resources, that is, resources contained in wisdom education; learners refer to people who learn, including not only students but also college teachers; The interaction between college teachers and students in class is learning activities; network terminal equipment and the software of all kinds of learning resources used by students and college teachers. At present, all colleges and universities in China can meet the requirements of constructing intelligent education. In order to promote the quality of education management in colleges and universities, it is necessary for colleges and universities to create intelligent education learning platform for teachers and students.

Teachers in colleges and universities can carry out stratified teaching to students according to their knowledge level, classroom feedback and students' learning ability, divide students with similar comprehensive ability into one group, arrange different teaching resources, teaching progress, teaching objectives according to the characteristics of different groups, and realize multi-level teaching, so as to solve the defects that traditional education methods can not be targeted to stratified teaching students. College teachers can arrange different homework contents for students through the learning platform of wisdom education. Through students' homework, college teachers can accurately grasp the real learning situation of each student. Can carry on the pertinence teaching and the guidance to the study. Teachers in colleges and universities can put the examination into the learning platform of wisdom education, design the examination content according to the students' different learning progress and teaching objectives, and let the students carry out the examination at the same time or in batches, thus reflecting the flexible and diverse teaching methods of wisdom education ${ }^{[2]}$.

Colleges and universities can learn from successful cases abroad to build a learning platform for wisdom education. In the wisdom education learning platform, middle school students can choose the knowledge they need to learn on the basis of their actual learning situation, so as to complete the construction of their own knowledge system. College teachers can also evaluate students' learning effect through wisdom education learning platform, so as to improve the efficiency of teaching management in colleges and universities.

\section{Scientific management of education}

One of the main manifestations of wisdom education in colleges and universities is the "campus card" introduced by colleges and universities at present. It embodies a kind of progress in teaching. It systematically manages and saves students' information. Students can use the campus card to simplify 
the management process on campus. For example, when students want to borrow books in the library, they can use the "campus card ". The computer can get the accurate information of the students and avoid the process of handling and checking the loan card. Students no longer need to find teachers or to see the results list, as long as they brush their own "campus card" in the access terminal can get their own results information. Such a small card not only allows students and teachers to get the information they need quickly and accurately, but also effectively reduces teacher management work ${ }^{[3]}$. Through the scientific management means of "Campus Card ", students not only have a better understanding of themselves, but also have contact with the new educational model of wisdom education. If colleges and universities want to carry out wisdom education on campus better, they must first break the traditional student management mode, introduce science and technology into the student management mode, and arm the teaching team with science and technology.

\section{Make the campus form into a scientific form}

College campus in people's inherent thinking of the campus form is serious, traditional, oldfashioned. With the strong admission of wisdom education to the campus, the campus form has changed, and gradually think of the transformation of science and technology and electronic form. Colleges and universities build an electronic campus through the network, collect the personal information of all students, and make all the teachers' courses into electronic courses, so that no matter which students delay the teacher's courses for any reason, You can learn the course after class through the electronic tutorial in the wisdom education platform. This kind of education mode can make students choose classes and listen to classes more quickly and conveniently. Students extend from classroom learning to students' mobile phones, computers, tablets. In order to enable students to better understand the advantages and benefits of wisdom education, college teachers can create a school public name for students to pay attention to. In this way, the traditional serious, dull, old-fashioned campus form into the form of science and technology and electronic form ${ }^{[4]}$.

\section{Improve students' learning ability based on wisdom education}

The wisdom education records the teaching of the whole process of college teachers before, in class and after class, so that the students can concentrate on the students through the wisdom education platform, so as to solve the problem of scattered and intermittent teaching in the traditional education time. Students use the wisdom education platform to learn the teacher's preview plan before class, 
and express their views on the topic released by the teacher, so that the teacher can understand the students' views and problems more clearly.With the rapid development of education in our country in recent years, colleges and universities pay more and more attention to the positive role of intelligent education platform in education management, and integrate classroom education and network education effectively through intelligent education platform. It can improve students' learning ability and adaptability $^{[5]}$.

The creation of teaching situation and the guidance of learning methods by college teachers are indispensable in the process of learning, in addition to the support and help of equipment, promoting scholars and resources. The creation of learning situation by college teachers effectively promotes the improvement of students' learning quality. In the process of traditional teaching in colleges and universities, students study in a fixed time and space, which is not conducive to the cultivation of students' innovative ability. The introduction of wisdom education in college teaching can solve the problem of cultivating students' innovative ability very well. Teachers can publish the created teaching situation on the network platform such as network forum, WeChat, Weibo and so on, and provide students with teaching video, learning tasks, unit test questions and so on on on the network platform. So that students can accept classroom teaching on the Internet, thus stimulating students"' adaptive "learning ability to improve effectively.

\section{Integrating the Idea of Wisdom Education into the Teaching Management of Colleges and Universities}

Wisdom education is the educational idea and mode produced under the background of big data. College teaching should not only make use of wisdom education to innovate teaching, but also make full use of concept and platform to improve the teaching mode of management education. Colleges and universities should make rational use of and develop wisdom education in the integration of enterprise unit practice and teaching process to help learners get relatively practical experience.The intelligent education platform can promote the integration of ideas and teaching in the education management of colleges and universities. Managers can use the platform of wisdom education to analyze all kinds of problems in teaching management in depth. The intelligent education platform can be used to help analyze students' learning time and interact with teachers on the network to monitor students' learning state, and then to manage and intervene students in time and effectively ${ }^{[6]}$.

\section{Conclusion}


The introduction of intelligent education into the teaching management of colleges and universities has promoted the development of teaching management in colleges and universities; the effective integration of teaching resources and Internet information technology in colleges and universities has improved the rational allocation of teaching resources and the utilization rate of teaching resources in colleges and universities. At the same time, wisdom education also dominates the channel of lifelong learning and the modernization development of continuing education. Wisdom education can not only enrich the content of continuing education and expand the object of continuing education, but also reduce the restrictions on continuing education and increase the number of people in continuing education.

Acknowledgement

This work is supported in part by key project of basic research business expenses of Zhejiang Financial College in 2019 "Research on innovation and practice of university education management mode in the era of big data" (No.: 2019ZD26)

\section{References}

[1] Xu Changlock. A Study on Innovation of Educational Management Mode in Colleges and Universities Based on the Background of Wisdom Education [J]. China High-tech Zone ,2019,(16):230230.

[2] Gu Jianfeng. Exploration on the Practice Path of Educational Management in Colleges and Universities from the Perspective of J]. Education China Adult Education ,2018,(18):55-57.

[3] Tian Lu. Exploration on the Practice Path of Educational Management in Colleges and Universities from the Perspective of J]. Education Youth ,2019,(5):136-136.

[4] Wang Jinna. Exploration on the Practice Path of Educational Management in Colleges and Universities from the Perspective of J]. Education Art Technology ,2018,31(10):228-228.

[5] Tan Xiao. Exploration on the Practice Path of Educational Management in Colleges and Universities from the Perspective of J]. Education Modern Economic Information ,2019(8):471-471.

[6] Yu Qiao E, Wang Lin Yi. A Study on the Innovative Application Mode of Intelligent Campus in Colleges and Universities from the Perspective of J]. Internet Theory ,2018,(4):208-209. 